\title{
Sustainability in Fashion: A Study of Clean Waste Management within a Clothing Company
}

\author{
H. Cruz \& A. C. Broega \& M. Amorim \\ University of Minho, Guimarães, Portugal
}

\begin{abstract}
The Apparel Industry is one of the most polluting industries due to the amount of waste that is created throughout the production process. It is essential to study this process to identify the problem, the causes and to propose solutions for a sustainable approach in this sector. This paper presents an exploratory study on the management of textile waste in Portugal in general and more specifically, through a case study in a confection clothing company.
\end{abstract}

\section{INTRODUCTION}

New consumers increasingly committed, require companies to work for increasing social and environmental responsibility, therefore, the entire market is returning to sustainability as a response to this requirement (Voltolini, 2012).

The fashion industry, especially the textile and clothing industry, as one of the industries with the most negative environmental impacts as a result of their residues, must make decisions towards sustainability.

\subsection{Objectives}

The main objective of this work is to create a database that gathers information on clean waste from the textile and clothing industries in Portugal, with a view to a more sustainable management of textile waste, by reducing or reusing it. This article aims to present the exploratory work done about textile waste management in Portugal in general, and in the specific case of a garment production company as a case study.

\subsection{Methodology}

First, this study will be based according to exploratory research, using qualitative methods, more specifically, a case study of a clothing company.

Furthermore, the dissertation project follows an approach of the "design thinking" methodology. For Cardon (2010), the "design thinking" methodology is a "useful tool that applies the creative and critical thinking to understand, visualize and describe the complex or poorly structured problems and then develop practical approaches to solve it."

According to Brown (2008), this process can be summarized in three phases: "inspiration", which is the identification of the real problem; "ideation", which is the process of creating ideas to generate innovations that can solve the problem, and "imple- mentation", which is summarized in the selection of the best idea and its execution.

The stages of this process sometimes are not linear so they may occur simultaneously or be repeated to achieve continuous innovation.

This article presents the results of phase "inspiration" by identifying the main problems in the waste management from the textile and clothing industry, through observation, study, display and analysis using the case study, more specifically, the study of a clothing company.

\section{THEORETICAL CONCEPTS}

\subsection{Fashion and Sustainability}

The fashion industry, namely the textile and clothing industry, is an economic potential that employs millions of people around the world, in spite of being also one of the most polluting to the environment (Black, S., 2008).

This is due mainly to the briefness of the life cycle of fashion products leading to the production and uncontrolled products consumption, with a programmed date of obsolescence every six months.

However, nowadays consumers begin to raise awareness on environmental issues, starting to prefer products developed with environmental and social responsibility policies.

In this sense, the brands are trying to adapt to this change of society consciousness that requires environmental and social responsibility, developing forms of production that are not so damaging to the environment (Morais \& Figueiredo, 2013). To answer these questions, companies are beginning to incorporate sustainability in the life cycle of fashion products throughout their development process.

\subsection{Apparel Industry Waste}

The waste management is one of the focuses of this research because the amount of textile waste in 
the Portuguese apparel industry is massive and can be managed to be used in other projects in a more sustainable way.

According to Thomas (2016), in Portugal, "Textile waste weigh annually is about 230 tons..." and $" . .5 \%$ of 4607 tons of municipal solid waste, is composed of clothing or household linen which end up in a landfill or incinerated." This happens because the industry is not interested in recycling used clothing as this results in less resistant fibbers and does not provide great profit (Thomas, 2016).

Furthermore, these residues are not only from textile products in end of life. The development process of these products also produces a lot of waste, particularly in the cutting phase of every clothing industry. These residues, which are mostly small pieces of fabric, are generated in tons of rowmaterials that are being disposed in landfills, which present a major problem for the economy of these companies and the environment.

\subsection{Sustainability}

Sustainability is a current topic much debated and induced as a solution to repair or at least minimize various actions that have been committed and that degrade our planet, for example, the global warming; the pollution; deforestation; among others. This damage is caused by several reasons but one of the main ones is industrialization. David Santilho and the organization "Forum for Future", highlighted some of the main problems caused by these industries, namely: "Consumption of Fashion; water consumption; the conditions of work; the energy expended; the use of chemicals; the carbon released duo to fabrics and transportation of garments around the world; the complexity of the supply chain and waste management" (Morais et al., s.d.).

Considering the factors mentioned above, there is a need for measures that can reduce waste, establishing a sustainable development.

Sustainable development is founded by the way companies pace themselves to the environment and society, taking actions to minimize the problems caused to nature. This development must be part of the business vision, based on the creation of sustainable products and using basic strategies such as the use of renewable energy sources and new technologies that can assist in the waste management. However, most companies still do not care about these problems and do not consider the concepts of sustainability.

\subsection{Sustainable Projects}

There are worldwide initiatives that bring these concepts mentioned above together, namely the fashion brands with eco-friendly principal of reuse of waste materials and this have resulted in innovative fashion products with added value.

Therefore, to carry out this research study, was necessary to realize the possible interactions between the textile and clothing industry and their waste. The cases presented below and carried out in different countries, are some examples:

The fashion brand "Contextura", located in Rio

Grande do Sul in Brazil, "is a textile research atelier that explores the interaction between art, design, handcraft, fashion and sustainability. Through out fieldwork, there is a selection in the industrial waste that can be converted into expressive raw materials to form new visual and tactile solutions in objects of art, fashion and decoration, through contemporary technology textile "collage" with eco-friendly adhesives" (Contexture, 2016).

The "Insecta Shoes" is a brand of vegan and ecological shoes, produced in Brazil. Their shoes are made from vintage clothing and plastic (PET) bottles recycled and there is not used any new raw material. The company also uses other sustainable strategies, such as the planting of trees needed to neutralize the $\mathrm{CO} 2$ emissions emitted; "the delivery of products are made by bicycle, which is a faster way and that does not pollute the environment" and many other methods that are always being improved with focus on sustainability (Insecta Shoes, 2016).

The "Darono" is a Portuguese brand that creates original interior design pieces, and have a great concern for environmental issues, using their own fibbers, consisting of "polymers, which are totally ecofriendly" (Darono, 2016).

The "Vintage For A Cause" is a project that transforms used fashion clothes in vintage clothing, the revenue of its sales are reversed in full to the sustainability of the same project. This project has the support of renowned designers such as Katty Xiomara and women over 50 years old who do not have a professional occupation (VintageForACause, 2016).

These are some examples of successful companies that are based on sustainability to create sustainable products with high environmental value and low production cost, making them into luxury goods with added value.

\section{RESULTS AND DISCUSSION}

After a brief literature review and the selection of the methodology, the development of this research goes through a case study.

First, there was a research on the apparel industry in general, highlighting the clothing industry and its waste to the perception and identification of the problem. As previously stated, the waste generated by the Apparel Industry in Portugal are about 230 tons per year and the majority corresponds to textile waste that is created throughout the garment produc- 
tion, mainly in the confection phase, consisting of remnants of fibbers or fabrics (Thomas, 2016).

Therefore one of the fundamental problems of this industry is the waste associated with the manufacturing process.

The waste generated industrially is classified according to the European Waste List, defined in Law 209/2004, and the codes used for textile waste are:

- 040109 - waste of confection and finishing;

- 040209 - composite materials waste (impregnated textile, elastomer and plastomer);

- 040215 - waste from the textile industry (mainly cut origin, confection, packing's, manufacturing process, and other processes in the textile industry);

- 040221 - wastes from unprocessed textile fibbers (mainly row-fibbers that have not undergone any processing);

- 040222 - processed fibbers waste (debris include fibbers, yarns, knitted and woven strips, lint, waste fibbers retained in the filters machines, and others);

- 150103 - textile packaging waste (used in cotton bales, for example).

The amount of waste produced in the textile and clothing companies are very variable, depending on the size of the company, its main activity and the steps involved in the production process.

In general, there is a separation of waste in these companies, although this process can vary from company to company, and some just separate the most common waste such as plastic and paper, and some more developed companies include more advanced procedures.

After being speared, the waste is delivered to authorized or licensed waste carriers, thus being sent for recovery or disposal. The waste sent for recovery can be recycled or reused and the one sent to eliminate, normally is placed in a landfill or deposited on the ground.

Data on textile waste were obtained from the National Statistics Institute (INE) and the Portuguese Environmental Agency (APA).

The following table represents the textile residues generated in recent years.

Table 1. Textile Waste in Portugal

\begin{tabular}{lcc}
\hline Date & $\begin{array}{c}\text { Textile } \\
\text { Waste }(\mathrm{t})\end{array}$ & $\begin{array}{c}\text { Waste } \\
\text { Management }(\mathrm{t})\end{array}$ \\
\hline 2015 & 54001 & 6335 \\
2014 & 49673 & 6759 \\
2013 & 44378 & 6648 \\
2012 & 42570 & 4646 \\
2011 & 63904 & 3666
\end{tabular}

\section{Source: INE}

As can be seen in Table 1, in 2015, 54,001 tons of textiles waste was produced in the industry from textiles, clothing, leather and leather goods.
In Figure 1 we can observe the types of waste (tons) produced in 2015 in textiles manufacturing, i.e. in all textile and clothing companies in Portugal, concluding that these are mainly textile waste (nonhazardous).

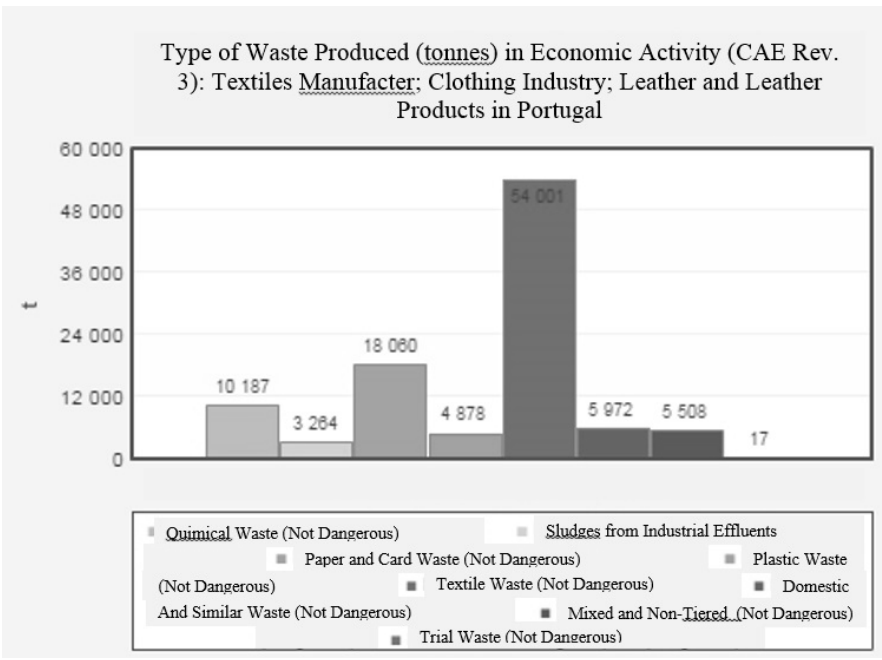

Figure 1. Types of Waste on Apparel Industry (Source: INE)

In Figure 2 we can observe the types of waste management operations that were used in 2015 in the textile and clothing companies in Portugal, showing that 84,351 tons of waste are recovered through recycling and recovery operations and 26465 tons are eliminated through disposal operations, being mainly placed in a landfill.

Figure 2. Types of Waste Management (Source: INE)

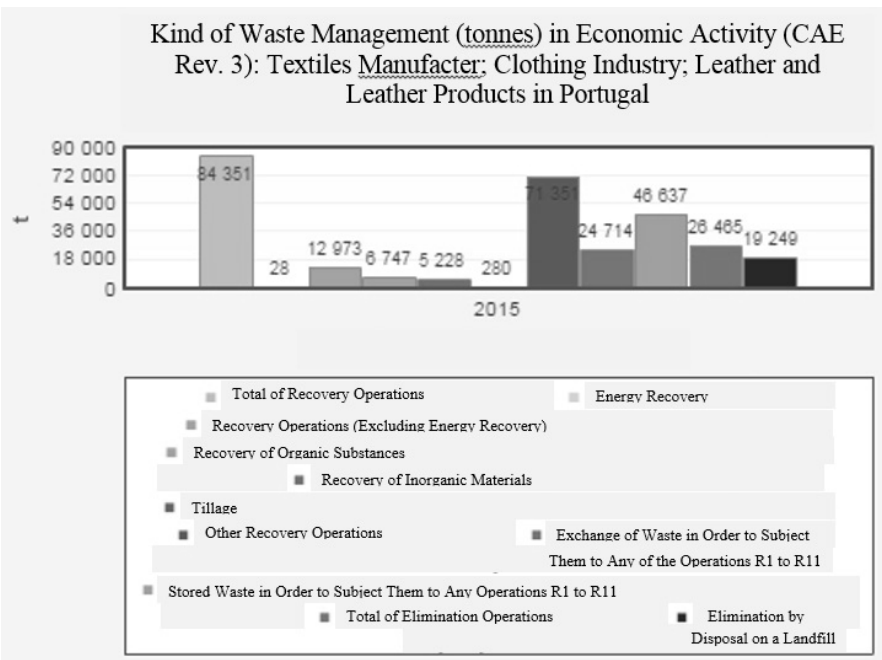

After this brief study, to better understand the problem, there was a study case.

\subsection{Study Case}

The company under study is a small/medium company in the north of Portugal in a textile area of excellency in the country. It is an SME of the textile confection sector and it began its activity in 1974 and its main activity is the manufacture of knitted clothes, whose production is entirely to export. 
Its main customers are the Next; Acne Studios; Zara; Moncler; BMW and Porsche.

As previously stated, this case study helps in the perception and identification of the problem, for better understanding of the problem.

Thus, this study consisted in the collection of data provided by the company in relation to solid waste generated annually and data provided by day-to-day observation. The observations allowed to verify that the main solid waste is composed of three different types: plastic, textiles, paper and cardboard (Table 2).

Table 2. Study Case Waste

\begin{tabular}{lccc}
\hline Data & Textile & Plastic & Paper \\
& Waste & Waste & Waste \\
Code & $(040215)$ & $(150102)$ & $(150101)$ \\
Weight & $(\mathrm{kg})$ & $(\mathrm{kg})$ & $(\mathrm{kg})$ \\
\hline 2016 (Jan-Jun) & 4940 & 206 & 7390 \\
2015 & 7980 & 512 & 8830 \\
\end{tabular}

As it can be seen in Table 2, while the textile waste produced in 2015 amounted to $7980 \mathrm{~kg}$, in the first six months of 2016, the amounts already was on $4940 \mathrm{~kg}$, which certainly implies that year will produce more textile waste than the year before.

It is possible to conclude, according to the data in Table 2, that the type of waste most produced is paper and cardboard, both in 2016 and in 2015, followed by textile waste. These wastes are sent and processed by the company Valor-Rib, which is a competent authority for waste treatment, and the last resort used for their elimination is the deposit in the soil (called D1 operation). The cost of treating textile waste for the company was about two hundred euros (until June) in 2016 and four hundred in 2015.

The Value-Rib can also carry out the sorting of recyclable products, including textiles, which are forwarded to the appropriate recyclers. However, according to company information, none of textile waste generated in this company was sent for this purpose.

During 2015, the company also sold some of its waste to a private client, including cutting waste and fabric waste, which made a recover of about a thousand euros for the company.

From these data collected it can be verified that the generation of waste is a serious environmental problem, as are almost 11 to 12 tons of annual waste to be disposed of in a landfill, besides being also a financial loss.

After this analysis, it was performed one observation of this waste within the company to better understand how it is produced and treated. During this process, it was concluded that the section that generates more waste is the cutting section.
In the images of Figures 5 and 6 it can be seen that the recollection of waste is done through two ducts on back of the cutting machine (Fig. 5). The only permitted separation at this point is: paper, cardboard and plastic, which are conducted to one of the conduits and the textile waste to another. At the end of the day, they are stored in containers (fig. 6) and then at the end of each month they are delivered to the competent authorities for their treatment. There is no separation or classification of textile waste either by colour or quality of raw materials.

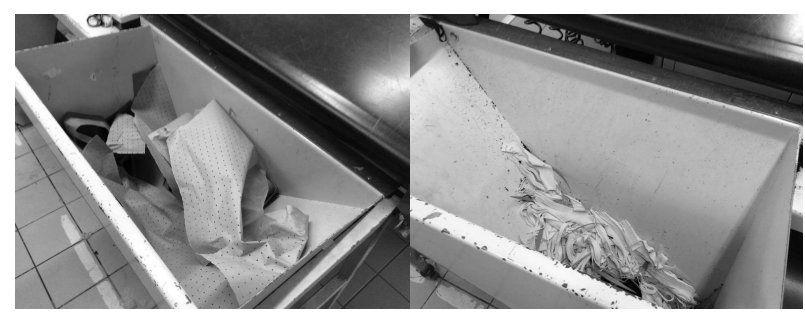

Figure 5. Separation Conduit on the Cutting Machine

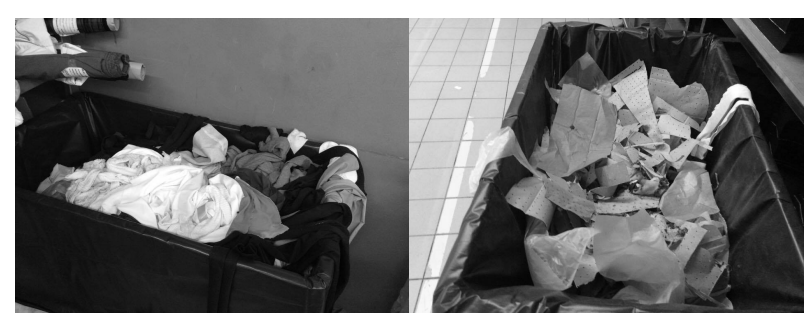

Figure 6. Stored Waste in Containers

\section{CONCLUSIONS}

The literature review for this project revealed the environmental issue of waste generated in the textile and clothing sector in the north of Portugal. This specific case study allowed a better identification of the problem of the waste generation and the way this is treated at the industrial level. From the data collected it is clear that the production of waste is a serious environmental problem, as about 11 tons of annual waste is disposed of in landfills, in addition to also be a financial loss.

It is possible however to identify actions that can make this process more sustainable, in environmental, social and economic point of view.

There are already some successful cases implemented in Portugal, working with the reuse of waste for the confection of new products.

As future prospects for this research, it is intended to work in waste management of this company (case study), in order not only to reduce their textile waste, but also to sort and organize it in order to be used as raw material for new products, either within the company or to other more creative businesses models and thus achieve more sustainable solutions for textile waste. 


\section{ACKNOWLEDGEMENTS}

"This work is supported by FEDER funds through the Competitivity Factors Operational Programme COMPETE and by national funds through FCT Foundation for Science and Technology within the scope of the project POCI-01-0145-FEDER007136"

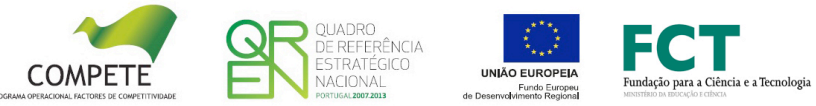

\section{REFERENCES}

APAmbiente. 2016. APAmbiente. Obtained from: http://www.apambiente.pt/.

Araújo, M. B. 2014. Marcas de Moda Sustentável: Critérios de Sustentabilidade e Ferramentas de Comunicação. Guimarães: Universidade do Minho.

Berlin, L. 2012. Moda e Sustentabilidade, uma reflexão necessária. São Paulo, Brasil: Estação das Letras e Cores.

Black, S. 2008. Eco-Chic - The Fashion Paradox. London: Black Dog Publishing.

Brown, T. 2008. Design Thinking. Obtained from: http://www.ideo.com/images/uploads/news/pdfs/IDEO HB R_Design_Thinking.pdf.

Cardon, E. C. 2010. Unleashing design: planning and the art of battle command. Military Review.

Carli, A. M., Cavalheiro, I., \& Brisotto , P. 2007. Novos Valores e Novas Práticas para o Design de Moda: Parcerias Artesanato/Indústria. Caxias do Sul: Universidade de Caxias do Sul.

Contextura. 2016. ShopContextura. Obtained from ShopContextura: https://www.shopcontextura.com/cms/sobre-acontextura.

Darono, 2016. Darono. Obtained from Darono: http://www.darono.pt/?page id=118\&lang=PT.

INE, 2016. INE. Available at: https://www.ine.pt/xportal/xmain?xpgid=ine_main\&xpid=I NE.

InsectaShoes, 2016. InsectaShoes. Available at: http://www.insectashoes.com/p/sobre-a-insecta.

Morais, C., \& Figueiredo, M. C. 2013. A Sustentabilidade no Design de Vestuário. Lisboa: Universidade Técnica de Lisboa.

Morais, C., Carvalho, C., \& Broega, C. Metodologia de EcoDesign no Ciclo de Moda: Reutilização e Reciclagem do Despedício de Vestuário. Unniversidade do Minho. Obtido em 16 de 12 de 2015

Oenning, J. 2012. Slow Fashion: Um caminho possível para o Design de Moda Sustentável. Universidade do Minho.

Schulte, N., \& Lopez, L. 2007. Sustentabilidade Ambiental no Produto de Moda. Brasil.

Tomás , C. 2016. 230 Toneladas de Roupa Vão para o Lixo. Expresso. Obtido em 16 de Janeiro de 2016.

VintageForACause, 2016. VintageForACause. Available at: http://vintageforacause.pt/quem-somos/.

Voltolini, Ricardo. Liderança para a sustentabilidade, um recurso renovável. 2012. Obtained fromAkatu: http://www.akatu.org.br/Temas/Sustentabilidade/Posts/Lide ranca-para-a-sustentabilidade-um-recurso-renovavel. Acesso em: 14 Agosto de 2016. 